\title{
Effects of Annual Applications of Low N Fer- tilizer Rates on a Mixed Grass Prairie
}

\author{
FRANK RAUZI AND MERLE L. FAIRBOURN
}

\begin{abstract}
Nitrogen (N) fertilizer at rates of 0,22 , and $34 \mathrm{~kg} / \mathrm{ha}$ was applied annually in the spring or fall over a 5-year period to a mixed grass prairie. Major species present were blue grama (Bouteloua gracilis), western wheatgrass (Agropyron smithii), and dryland sedges (Carex Sp.). Slim leaf goosefoot (Chenopodium leptophyllum) and other annual and perennial forbs were also present. Total herbage production, crude protein content, mineral concentrations, species composition and water use data were collected. Total herbage yields and crude protein from all the fertilizer treatments were significantly greater as compared with the control. Nearly all of the variation in phosphorus $(P)$, calcium $(C a)$, potassium $(K)$, and magnesium (Mg) concentrations and species composition were associated with the seasonal distribution of precipitation (years) and not with $\mathbf{N}$-fertilization treatments.
\end{abstract}

Extensive research has been done with both annual and single applications of nitrogen (N) to native rangelands. Smika et al. (1965) reported annual applications of $0,45,90$, and $180 \mathrm{~kg} \mathrm{~N} /$ ha with 2 different soil water treatments. Lorenz and Rogler (1972) reported an 8-year study in North Dakota using annual applications of $0,45,90$, and $180 \mathrm{~kg} \mathrm{~N} /$ ha with and without elemental phosphorus. Wight and Black (1979) studied the effect of annual applications of 0 and $45 \mathrm{~kg} \mathrm{~N} /$ ha over a 10 -year period in Montana, and also a single application of $336 \mathrm{~kg} \mathrm{~N} /$ ha vs. annual rate equivalent $(336,168$, and $42 \mathrm{~kg} \mathrm{~N} /$ ha for first, second, and eighth years, respectively). Power (1981) reported a detailed study of the effect of single high rate applications of $N$ vs. annual rate equivalent. One time applications of high $\mathrm{N}$ rates on rangelands have been reported by Johnston et al. (1967), Houston and Hyder (1975), and Rauzi (1977). Single applications of low N rates ( 22 to $34 \mathrm{~kg} \mathrm{~N} / \mathrm{ha}$ ) have not been successful. Lodge (1959) reported that application rates below $34 \mathrm{~kg} \mathrm{~N} /$ ha in southwestern Canada did not significantly increase dry matter production. Woodmansee et al. (1978) found that $30 \mathrm{~kg} \mathrm{~N} / \mathrm{ha}$ are needed to support annual plant growth on a shortgrass prairie ecosystem. Westin et al. (1955) studied the residual effects of $0,22,45$, and $90 \mathrm{~kg} \mathrm{~N} /$ ha on native range forage production in western South Dakota. They found that $90 \mathrm{~kg} \mathrm{~N} / \mathrm{ha}$ applied once in 3-years produced more hay per unit of $\mathrm{N}$ than did $30 \mathrm{~kg} /$ year applied annually over a 3 -year period. Rogler and Lorenz (1957) applied annual applications of $34 \mathrm{~kg} \mathrm{~N} /$ ha over a 6-year period and doubled the yields from a mixed grass prairie near Mandan, N. Dak.

The purpose of this study was to determine if there are residual $\mathrm{N}$ effects with time from either spring or fall applications of 22 and 34 $\mathrm{kg} \mathrm{N} /$ ha rates on total dry matter production, crude protein content, forage mineral concentrations, species composition, and forage water use. Crude protein and mineral concentrations are shown for only the 3 major species.

\section{Study Area and Procedure}

The study, conducted from 1974 through 1979, was located in southeastern Wyoming at the USDA High Plains Grasslands

\footnotetext{
Authors are soil scientist (retired), USDA-Agricultural Research Service, Laramie, Wyo. 82071; and soil scientist, USDA-Agricultural Research Service, High Plains Grasslands Research Station, 8408 Hildreth Road, Cheyenne, Wyo. 82001, respectively.

Manuscript received July 5, 1981.
}

Research Station, approximately $7 \mathrm{~km}$ west of Cheyenne at an altitude of about $1900 \mathrm{~m}$. The soil on the experimental a rea was an Altvan fine, sandy, clay loam, a member of the mixed, mesic family of Aridic Arguistols (Young and Singleton 1977). Altvan soils are on nearly level to gently sloping fans and terraces of granitic origin and are noncalcareous to $60 \mathrm{~cm}$. The 0 to $15 \mathrm{~cm}$ soil depth has a 7.1 $\mathrm{pH}$ (dilution), $3.5 \%$ organic matter, and $37 \mathrm{~kg} /$ ha sodium bicarbonate extractable phosphorus. The soil to the $120 \mathrm{~cm}$ depth holds about $13 \mathrm{~cm}$ of water available to plants. Major plant species of the mixed grass prairie consisted of blue grama (Bouteloua gracilis), western wheatgrass (Agropyron smithii), and dryland sedges (Carex sp.). Other grasses present included needleandthread (Stipa comata), junegrass (Koeleria cristata) and sandberg bluegrass (Poa secunda). Annual and perennial forbs were also present and their abundance varied with the prevailing weather.

The experimental design was a randomized block with 5 fertilizer treatments and 3 replications. Ammonium nitrate was applied annually in the spring and fall at rates of 0,22 , and $34 \mathrm{~kg} \mathrm{~N} /$ ha to 24 by $30 \mathrm{~m}$ plots. Fertilizer applications were made each year in late October or March for fall and spring, respectively. Five $0.18 \mathrm{~m}^{2}$ subplot sample areas were randomly located annually on each main plot and the previous year's vegetation was removed to ground level by hand rubbing the soil surface in the spring before the initiation of new plant growth. Harvest of the subplots was done by clipping to ground level and separating the vegetation by species. The mature vegetation was harvested each year during August and the plant material was weighed and ground in a stainless steel mill equipped with a 40 -mesh screen. Crude protein (Kjeldahl $\mathrm{N} \times 6.25$ ) was determined by the Kjeldahl procedure (Bremner 1965). Phosphorus (P) was determined by the vanadomolybdophosphoric yellow-color method in nitric acid system (Jackson 1958). Calcium (Ca), potassium (K), and magnesium $(\mathrm{Mg})$ were determined by atomic absorption spectrophotometry on a perchloric acid digest. All data were reported on a dry weight basis.

Neutron access tubes were placed in each main plot and soil water measurements in \% by volume were made near April 1 of each year and at monthly intervals throughout the growing season. Water use efficiency for each plot was determined by adding the centimeters of water used from the soil to the growing season precipitation and dividing the total centimeters of water into the dry matter yield. Water used was evapotranspiration.

Analysis of variance was made on data for a randomized block design and Duncan's multiple range test was applied at the 5\% level of probability.

\section{Results and Discussion}

\section{Herbage Yields}

The amount and distribution of precipitation during the growing season influenced $\mathrm{N}$ response in herbage production. Western wheatgrass is a cool-season species and responds to early spring soil water while blue grama, a warm-season species, responds to July and August precipitation.

The April through July precipitation was variable and generally least in April and greatest in May (Table 1). Even though the May precipitation was greater than for other months, the western 
Table 1. Annual and April through July precipitation (mm) for 1975 through 1979 at the High Plains Grasslands Research Station, Cheyenne, Wyo. (Unshielded rain gauge).

\begin{tabular}{lcccccc}
\hline \hline Year & Annual & April & May & June & July & Total \\
\hline 1975 & 324 & 20 & 71 & 54 & 47 & 192 \\
1976 & 343 & 48 & 60 & 42 & 92 & 242 \\
1977 & 351 & 47 & 68 & 50 & 101 & 266 \\
1978 & 319 & 13 & 115 & 79 & 8 & 215 \\
1979 & 440 & 17 & 71 & 71 & 46 & 205 \\
Average & 355 & 29 & 77 & 59 & 59 & 224 \\
\hline
\end{tabular}

wheatgrass did not show significant herbage yield differences among treatments (Table 2). While the yields from 1976 through 1979 showed a trend toward an increase of western wheatgrass production on the fertilizer treatments, the differences were not significant due to wide variability in two or more treatments each year. However, average annual dry matter yields increased from 204 in 1975 to $395 \mathrm{~kg} / \mathrm{ha}$ in 1979 . The 1979 average yields were significantly greater than for other years suggesting that 1979 conditions with above average precipitation in March, and June were near optimum for this species. On an annual basis, yields of blue grama were not significantly different between treatments, but the 5-year average shows that the $22 \mathrm{~kg} \mathrm{~N} /$ ha spring applied treatment produced significantly more dry matter than the control. There were significant differences in average yields of blue grama between years, with the greatest yields occurring in 1977, a year of relatively high July precipitation. The dryland sedges had no production increase from the $\mathbf{N}$ treatments, but were significantly different between years with a marked decrease in 1977 and 1979. Forb production, mainly slim leaf goosefoot (Chenopodium leptophyllum), increased on all $\mathrm{N}$ treatments, but especially on the $34 \mathrm{~kg}$ $\mathrm{N} / \mathrm{ha}$ treatments. During the 5-year period, forbs accounted for 22 , 25 , and $26 \%$ of the total herbage produced on treatments of $22 \mathrm{~kg}$ $\mathrm{N} /$ ha spring, $34 \mathrm{~kg} \mathrm{~N} / \mathrm{ha}$ spring, and $34 \mathrm{~kg} \mathrm{~N} /$ ha fall, respectively. The yields of forbs were due mainly to the 1979 production. The forb species made a rapid response to $\mathrm{N}$ fertilization that year. While precipitation for April was below normal, it had been greater than average during March. Significant differences in 1979 total herbage yields resulting from the $\mathrm{N}$ treatments were mainly
Table 2. Average 5-year production (kg/ha) of western wheatgrass, blue grama, dryland sedges, and forbs; and total annual herbage from a mixed prairie range fertilized annually spring or fall with 0,22 , or $34 \mathrm{~kg}$ N/ha, at the High Plains Grasslands Research Station, Cheyenne, Wyo., 1975 through 1979.

\begin{tabular}{|c|c|c|c|c|c|c|}
\hline \multirow[b]{3}{*}{ Species \& year } & \multirow[b]{3}{*}{ Controli } & \multicolumn{5}{|c|}{ Fertilizer $\mathrm{N}$ applied $(\mathrm{kg} / \mathrm{ha})$} \\
\hline & & \multicolumn{2}{|c|}{ Spring } & \multicolumn{2}{|c|}{ Fall } & \multirow[b]{2}{*}{ Mean } \\
\hline & & 22 & 34 & 22 & 34 & \\
\hline $\begin{array}{l}\text { Western } \\
\quad \text { wheatgrass } \\
\text { Blue grama } \\
\text { Dryland sedges } \\
\text { Forbs }\end{array}$ & $\begin{array}{l}161^{a_{1}} \\
400^{b} \\
162^{a} \\
113^{c}\end{array}$ & $\begin{array}{l}271^{\mathrm{a}} \\
473^{\mathrm{a}} \\
135^{\mathrm{a}} \\
271^{\mathrm{ab}}\end{array}$ & $\begin{array}{l}277^{\mathrm{a}} \\
421^{\mathrm{ab}} \\
162^{\mathrm{a}} \\
297^{\mathrm{a}}\end{array}$ & $\begin{array}{l}209^{2} \\
445^{\mathrm{ab}} \\
206^{\mathrm{a}} \\
146^{\mathrm{bc}}\end{array}$ & $\begin{array}{l}301^{\mathrm{a}} \\
445^{\mathrm{ab}} \\
163^{\mathrm{a}} \\
324^{\mathrm{a}}\end{array}$ & \\
\hline $\begin{array}{l}\text { Total herbage } \\
1975 \\
1976 \\
1977 \\
1978 \\
1979\end{array}$ & $\begin{array}{r}848^{a} \\
759^{b} \\
760^{c} \\
803^{c} \\
1087^{b}\end{array}$ & $\begin{array}{c}871^{\mathrm{a}} \\
1205^{\mathrm{a}} \\
1170^{\mathrm{a}} \\
1066^{\mathrm{ab}} \\
1730^{\mathrm{ab}}\end{array}$ & $\begin{array}{c}963^{\mathrm{a}} \\
1177^{\mathrm{a}} \\
1028^{\mathrm{ab}} \\
1020^{\mathrm{ab}} \\
1711^{\mathrm{ab}} \\
\end{array}$ & $\begin{array}{c}854^{\mathrm{a}} \\
1049^{\mathrm{a}} \\
908^{\mathrm{b}} \\
950^{\mathrm{b}} \\
1408^{\mathrm{ab}} \\
\end{array}$ & $\begin{array}{r}937^{\mathrm{a}} \\
1176^{\mathrm{a}} \\
1038^{\mathrm{ab}} \\
1151^{\mathrm{a}} \\
1926^{\mathrm{a}} \\
\end{array}$ & $\begin{array}{c}895^{c} \\
1073^{b} \\
981^{b c} \\
998^{b c} \\
1572^{a}\end{array}$ \\
\hline Mean & $851^{c}$ & $1208^{a}$ & $1179^{a}$ & $1034^{b}$ & $1245^{a}$ & \\
\hline
\end{tabular}

IValues followed by the same letter for a species or total herbage within a year, in vertical mean column, or as a horizontal mean are not significant at the 0.05 level.

due to production by the western wheatgrass and forbs.

\section{Crude Protein}

The average percent crude protein of western wheatgrass, blue grama and dryland sedges was significantly increased by $\mathbf{N}$ treatments over that of the control (Table 3). Crude protein concentration of the 3 species varied significantly between years, perhaps due to distribution and amount of precipitation. The fertilized vegetation produced an average of 32 to $40 \mathrm{~kg} / \mathrm{ha}$ more protein annually than the control, and the palatability of the grasses and dryland sedges may have been enhanced (Samuel et al. 1980). However, increased crude protein production did not economically justify the fertilization treatments.

Phosphorus, Calcium, Magnesium, and Potassium

Average concentrations of $\mathrm{P}, \mathrm{Ca}, \mathrm{Mg}$, and $\mathrm{K}$ of the three major species are shown in Table 4. Since these species were essentially

Table 3. Crude protein (\%), in western wheatgrass, blue grama and dryland sedges from a mixed prairie range fertilized annually, spring or fall, with 0 , 22, or $34 \mathrm{~kg} \mathrm{~N} / \mathrm{ha}$ at the High Plains Grasslands Research Station, Cheyenne, Wyo., from 1975 through 1979.

\begin{tabular}{|c|c|c|c|c|c|c|}
\hline \multirow[b]{2}{*}{ Species and year } & \multirow[b]{2}{*}{ Control } & \multicolumn{2}{|c|}{ Spring } & \multicolumn{2}{|l|}{ Fall } & \multirow[b]{2}{*}{ Mean } \\
\hline & & $22 \mathrm{~kg} \mathrm{~N} / \mathrm{ha}$ & $34 \mathrm{~kg} \mathrm{~N} / \mathrm{ha}$ & $22 \mathrm{~kg} \mathrm{~N} / \mathrm{ha}$ & $34 \mathrm{~kg} \mathrm{~N} / \mathrm{ha}$ & \\
\hline $\begin{array}{l}\text { Western wheatgra } \\
1975 \\
1976 \\
1977 \\
1978 \\
1979\end{array}$ & $\begin{array}{r}7.3^{\mathrm{a}} 1 \\
12.0^{\mathrm{a}} \\
11.8^{\mathrm{b}} \\
7.8^{\mathrm{a}} \\
8.8^{\mathrm{a}} \\
\end{array}$ & $\begin{array}{r}10.5^{\mathrm{a}} \\
15.5^{\mathrm{a}} \\
14.4^{\mathrm{a}} \\
9.3^{\mathrm{a}} \\
10.2^{\mathrm{a}} \\
\end{array}$ & $\begin{array}{r}9.6^{\mathrm{a}} \\
13.7^{\mathrm{a}} \\
13.8^{\mathrm{a}} \\
9.4^{\mathrm{a}} \\
10.5^{\mathrm{a}} \\
\end{array}$ & $\begin{array}{c}9.4^{\mathrm{a}} \\
13.3^{\mathrm{a}} \\
12.4^{\mathrm{ab}} \\
9.1^{\mathrm{a}} \\
10.3^{\mathrm{a}} \\
\end{array}$ & $\begin{array}{r}9.5^{\mathrm{a}} \\
14.1^{\mathrm{a}} \\
14.4^{\mathrm{a}} \\
9.7^{\mathrm{a}} \\
9.9^{\mathrm{a}} \\
\end{array}$ & $\begin{array}{r}9.3^{\mathrm{c}} \\
13.7^{\mathrm{a}} \\
13.4^{\mathrm{a}} \\
9.1^{\mathrm{c}} \\
9.9^{\mathrm{b}}\end{array}$ \\
\hline Mean & $9.5^{c}$ & $12.0^{n}$ & $11.4^{b}$ & $10.9^{b}$ & $11.5^{\mathrm{ab}}$ & \\
\hline $\begin{array}{c}\text { Blue grama } \\
1975 \\
1976 \\
1977 \\
1978 \\
1979\end{array}$ & $\begin{array}{r}8.9^{a} \\
10.8^{b} \\
9.8^{b} \\
9.2^{c} \\
8.8^{b} \\
\end{array}$ & $\begin{array}{l}11.8^{\mathrm{a}} \\
13.6^{\mathrm{a}} \\
11.7^{\mathrm{a}} \\
11.9^{\mathrm{ab}} \\
11.4^{\mathrm{a}} \\
\end{array}$ & $\begin{array}{r}9.6^{\mathrm{a}} \\
13.8^{\mathrm{a}} \\
11.9^{\mathrm{a}} \\
12.2^{\mathrm{a}} \\
11.3^{\mathrm{a}} \\
\end{array}$ & $\begin{array}{l}11.0^{\mathrm{a}} \\
14.0^{\mathrm{a}} \\
10.5^{\mathrm{b}} \\
11.4^{\mathrm{ab}} \\
12.4^{\mathrm{a}} \\
\end{array}$ & $\begin{array}{l}11.8^{\mathrm{a}} \\
14.1^{\mathrm{a}} \\
11.9^{\mathrm{a}} \\
11.4^{\mathrm{ab}} \\
11.5^{\mathrm{a}}\end{array}$ & $\begin{array}{l}10.6^{\mathrm{b}} \\
13.3^{\mathrm{a}} \\
11.2^{\mathrm{b}} \\
11.2^{\mathrm{b}} \\
11.1^{\mathrm{b}}\end{array}$ \\
\hline Mean & $9.5^{b}$ & $12.1^{\mathrm{a}}$ & $11.3^{a}$ & $11.9^{n}$ & $12.1^{2}$ & \\
\hline $\begin{array}{l}\text { Dryland sedges } \\
1975 \\
1976 \\
1977 \\
1978 \\
1979\end{array}$ & $\begin{array}{r}9.9^{\mathrm{a}} \\
12.9^{\mathrm{b}} \\
11.4^{\mathrm{c}} \\
9.6^{\mathrm{b}} \\
9.1^{\mathrm{b}} \\
\end{array}$ & $\begin{array}{l}12.9^{\mathrm{a}} \\
16.4^{\mathrm{a}} \\
13.7^{\mathrm{a}} \\
12.3^{\mathrm{a}} \\
11.3^{\mathrm{a}}\end{array}$ & $\begin{array}{l}12.6^{\mathrm{a}} \\
15.0^{\mathrm{ab}} \\
13.1^{\mathrm{ab}} \\
12.9^{\mathrm{a}} \\
11.6^{\mathrm{a}} \\
\end{array}$ & $\begin{array}{l}11.5^{\mathrm{a}} \\
15.0^{\mathrm{ab}} \\
12.1^{\mathrm{bc}} \\
13.0^{\mathrm{a}} \\
12.1^{\mathrm{a}} \\
\end{array}$ & $\begin{array}{l}12.5^{\mathrm{a}} \\
15.7^{\mathrm{a}} \\
13.6^{\mathrm{a}} \\
12.5^{\mathrm{a}} \\
11.6^{\mathrm{a}} \\
\end{array}$ & $\begin{array}{l}11.9^{\mathrm{c}} \\
15.0^{\mathrm{a}} \\
12.8^{\mathrm{b}} \\
12.1^{\mathrm{c}} \\
11.1^{\mathrm{d}}\end{array}$ \\
\hline Mean & $10.6^{b}$ & $13.3^{\mathrm{a}}$ & $13.0^{\circ}$ & $12.7^{a}$ & $13.2^{\mathrm{a}}$ & \\
\hline
\end{tabular}

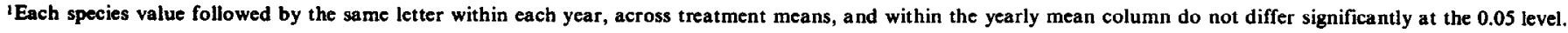


Table 4. Average phosphorus, calcium, potassium and magnesium percent concentrations in western wheatgrass, blue grama, and dryland sedges from a mixed grass prairie range fertilized annually spring or fall with 0,22 , or $34 \mathrm{~kg}$ N/ha from 1976 through 1979 at the High Plains Grasslands Research Station, Cheyenne, Wyo.

\begin{tabular}{|c|c|c|c|c|c|}
\hline \multirow[b]{2}{*}{ Element } & \multirow[b]{2}{*}{ Control } & \multicolumn{2}{|c|}{ Spring } & \multicolumn{2}{|c|}{ Fall } \\
\hline & & $22 \mathrm{~kg} \mathrm{~N} / \mathrm{ha}$ & $34 \mathrm{~kg} \mathrm{~N} / \mathrm{ha}$ & $22 \mathrm{~kg} \mathrm{~N} / \mathrm{ha}$ & $34 \mathrm{~kg} \mathrm{~N} / \mathrm{ha}$ \\
\hline & & \multicolumn{4}{|c|}{ Western wheatgrass } \\
\hline Phosphorus & $.15 \mathrm{a}^{*}$ & $.13 a$ & $.14 a$ & $.14 \mathrm{a}$ & $.14 a$ \\
\hline Calcium & $.37 \mathrm{a}$ & $.36 a$ & $.34 a$ & $.34 a$ & $.34 a$ \\
\hline Potassium & $1.26 \mathrm{a}$ & $1.42 \mathrm{a}$ & $1.35 \mathrm{a}$ & $1.23 \mathrm{a}$ & $1.42 \mathrm{a}$ \\
\hline \multirow[t]{2}{*}{ Magnesium } & $.06 a$ & $.05 a$ & $.06 a$ & $.07 a$ & $.07 a$ \\
\hline & & \multicolumn{4}{|c|}{ Blue grama } \\
\hline Phosphorus & $.16 \mathrm{a}$ & $.14 a$ & $.16 a$ & $.15 a$ & $.15 \mathrm{a}$ \\
\hline Calcium & $.48 \mathrm{a}$ & $.40 \mathrm{~b}$ & $.43 \mathrm{ab}$ & $.44 a b$ & $.41 \mathrm{ab}$ \\
\hline Potassium & $.85 a$ & $.86 a$ & $.75 a$ & $.78 \mathrm{a}$ & $.79 a$ \\
\hline \multirow[t]{2}{*}{ Magnesium } & $.08 \mathrm{a}$ & $.09 \mathrm{a}$ & $.08 \mathrm{a}$ & $.08 \mathrm{a}$ & $.08 a$ \\
\hline & & & \multicolumn{3}{|c|}{ Dryland sedges } \\
\hline Phosphorus & $.14 \mathrm{a}$ & $.14 a$ & $.14 a$ & $.13 a$ & $.14 a$ \\
\hline Calcium & $.48 \mathrm{a}$ & $.41 b$ & $.46 \mathrm{ab}$ & $.44 a b$ & $.42 \mathrm{ab}$ \\
\hline Potassium & $1.17 \mathrm{a}$ & $1.27 \mathrm{a}$ & $1.20 \mathrm{a}$ & $1.14 \mathrm{a}$ & $1.23 \mathrm{a}$ \\
\hline Magnesium & $.09 a$ & $.10 \mathrm{a}$ & $.09 a$ & $.09 a$ & $.08 a$ \\
\hline
\end{tabular}

*Each species value followed by the same letter for an element does not differ significantly at the .05 level.

mature, the nutrition is similar to what livestock would obtain from winter pasture of the forage. Nutrient levels of $\mathbf{P}$ and $\mathbf{M g}$ were below nutritional requirements of grazing animals during some years. The National Research Council (1968 and 1970) has listed the requirements as follows:

$\begin{array}{lcccc} & \mathbf{P} & \mathbf{C a} & \mathbf{M g} & \mathbf{K} \\ & (\boldsymbol{\%}) & (\%) & (\%) & (\%) \\ \text { Sheep } & 0.16-0.21 & 0.22-0.34 & 0.18-0.20 & 0.6-0.8 \\ \text { Cattle } & 0.16 & 0.18-0.22 & 0.18 & 0.6-0.8\end{array}$

Average phosphorus concentration in western wheatgrass, blue grama and dryland sedges, showed no significant differences due to treatments. However, all 3 species had differences in $P$ levels between years. Except for 1976 , most $P$ concentrations were relatively low, possibly bccause of $\mathbf{P}$ being tied up in decaying plant material accumulated from the first years of the study.

The Ca concentration of the western wheatgrass, blue grama and dryland sedges varied between years. Calcium concentration of blue grama and dryland sedges for the spring $22 \mathrm{~kg} \mathrm{~N} /$ ha treatment was significantly less than that of the control. This may be due to increased growth and thus a dilution of $\mathrm{Ca}$ resulting from the fertilizer treatment. Adequate $\mathrm{Ca}$ for nutritional requirements was expected in the forage since Altvan soil has a relatively high amount of exchangeable $\mathrm{Ca}$ (Fairbourn and Batchelder 1980).

The $K$ concentrations in the three species varied between years, whereas there was no significant difference between treatments. This result could be due to the differences in size of and time between precipitation events which would cause variations in the leaching of $\mathbf{K}$ into the soil from decaying plant materials. Temperature variations may also have affected $K$ uptake. The $K$ concentrations in the plant material were generally not great enough to cause a nutrient imbalance that could depress $\mathrm{Mg}$ utilization (Fairbourn 1980).

The $\mathbf{M g}$ concentration of the 3 species showed no significant differences between treatments. The 1977 concentrations in the blue grama and dryland sedges were significantly lower than concentrations in other years. The $\mathrm{Mg}$ in these forages was only 30 to $50 \%$ of the level livestock require for adequate nutrition.

\section{Species Composition}

The vegetation dry matter composition by species was influenced by $\mathbf{N}$ treatments and weather as shown by the data of Figure 1. The 1979 forb production referred to earlier caused a sharp decline in blue grama and carex yields that year. These species were less competitive with the forbs than western wheatgrass, probably because it starts growth early in the season. The blue grama dry matter increase in 1977 appeared to be a response to the June and July precipitation. Changes in botanical composition of the forage were not especially noticeable except for the slim leaf goosefoot in 1979. This species was very responsive to the $\mathbf{N}$ treatments when moisture and energy were relatively high.

\section{Soil Water}

The $13 \mathrm{~cm}$ of available soil water for plant use, if present, is held mainly in the top $60 \mathrm{~cm}$ of the Altvan soil profile. The coarse sand and gravel material below the $60-\mathrm{cm}$ depth is not capable of of holding much available water for plant use. Thus, a greater portion of the stored soil water was positionally a vailable for loss through evaporation than would occur in a soil of greater depth (Gardner and Gardner 1969). During the 5 years of this study, $75 \%$ of the growing season precipitation events measured $1 \mathrm{~cm}$ or less, contributing little to soil water storage. The neutron soil water measurements indicated the amount of water used from the soil by the native range plants during a season varied from 0 to $3.9 \mathrm{~cm}$ and was usually less than $1.5 \mathrm{~cm}$ because of availability. There appeared to be no consistent trend in soil water use with any of the fertilizer treatments.
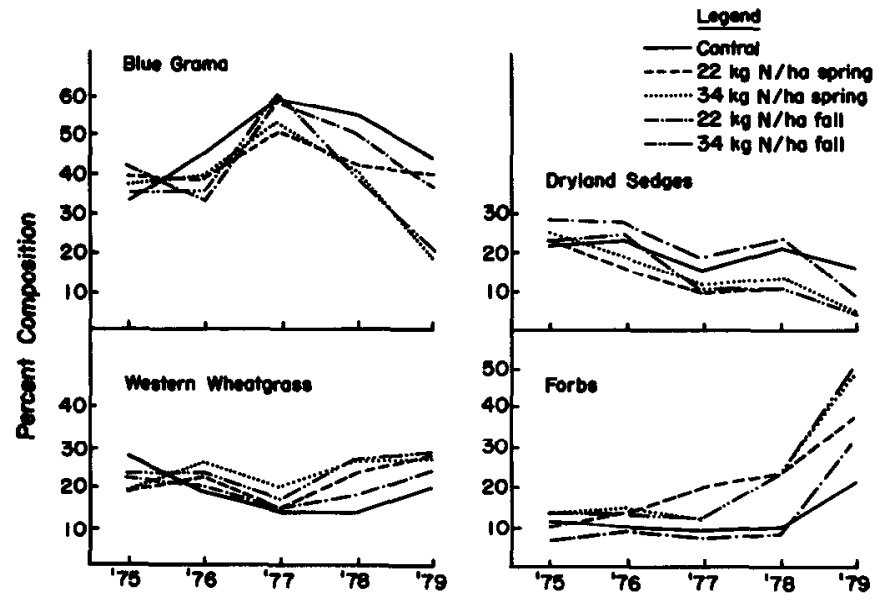

Fig. 1. Species percent dry matter composition by weight over a 5-year period from a mixed grass prairie fertilized with 0.22 or $34 \mathrm{~kg} \mathrm{~N} /$ ha each year in the spring or fall for 5 years, 1975 through 1979, at the High Plains Grasslands Research Station, Cheyenne, Wyo. 
Table 5 . Water use efficiency for $\mathrm{N}$-fertilized treatments of native range, 1975 through 1979, at Cheyenne, Wyo.

\begin{tabular}{|c|c|c|c|c|c|}
\hline Treatment & 1975 & 1976 & 1977 & 1978 & 1979 \\
\hline & \multicolumn{5}{|c|}{$-\mathrm{kg} / \mathrm{ha} / \mathrm{cm} \mathrm{H}_{2} \mathrm{O}$} \\
\hline $0 \mathrm{~kg} \mathrm{~N} / \mathrm{ha}$ & $45 a^{1}$ & $29 b$ & $27 a$ & $34 a$ & $51 \mathrm{~b}$ \\
\hline $22 \mathrm{~kg} \mathrm{~N} /$ ha-Spring & $42 a$ & $49 a$ & $44 a$ & $45 \mathrm{a}$ & $80 \mathrm{~b}$ \\
\hline $34 \mathrm{~kg} \mathrm{~N} /$ ha-Spring & $48 a$ & $49 a$ & $37 a$ & $41 a$ & $77 \mathbf{a}$ \\
\hline $22 \mathrm{~kg} \mathrm{~N} /$ ha-Fall & $42 a$ & $41 \mathrm{ab}$ & $33 a$ & $40 \mathrm{a}$ & $66 a b$ \\
\hline $34 \mathrm{~kg} \mathrm{~N} /$ ha-Fall & $44 a$ & $44 a b$ & $38 \mathbf{a}$ & $49 a$ & $84 \mathbf{a}$ \\
\hline
\end{tabular}

IValues followed by the same letter within colums do not differ significantly at the 0.05 level.

\section{Water Use Efriciency}

The fertilizer treatments did not make a significant difference in water use efficiency until 1979 (Table 5). This could have been due to two factors, precipitation distribution and residual $\mathrm{N}$-fertilizer effects. Precipitation events of $1 \mathrm{~cm}$ or more occurred during each month of the 1979 growing season and a more constant water supply was available for plant growth than for other years of the study. The residual $\mathrm{N}$-fertilizer effect could have been similar to that found by Wight and Black (1979) for a 45-kg N/ha annual application where maximum yield responses did not occur until after the fourth year of their study.

\section{Conclusions}

The annual application of 22 or $34 \mathrm{~kg} \mathrm{~N} /$ ha in either the spring or fall increased significantly the amount of total herbage produced compared to the control. Crude protein content in the western wheatgrass, blue grama, and dryland sedges was significantly increased by the $\mathbf{N}$ treatments. The dry matter production from the total herbage and the crude protein concentration of major species did indicate a sustained residual $\mathbf{N}$ effect after the first year of the study. However, the work of Power (1981) suggests the amount of annual residual $\mathrm{N}$ was small from low fertilizer rates of 22 and $34 \mathrm{~kg} \mathrm{~N} / \mathrm{ha}$. At this time, neither spring nor fall application appears to have an advantage.

Mineral composition of the species showed little response to the fertilizer treatments, but was mainly affected by annual weather differences during the study.

No great shift in vegetation composition occurred as a result of the $\mathbf{N}$ treatments except the 1979 increase in slim leaf goosefoot on all $\mathbf{N}$ treatments. Western wheatgrass increased on all treatments, but the increase was not significant until 1979.

Treatment differences in water use efficiency did not occur until 1979 and may have been due to precipitation distribution and residual $\mathbf{N}$.

The use of annual low rates of $\mathbf{N}$ for increasing herbage production is not economically practical because of the cost of the nitro- gen and energy to apply it. The main value of low $\mathrm{N}$ rates on rangelands would be to increase the palatability and crude protein of the herbage to enhance livestock grazing distribution.

\section{Literature Cited}

Bremner, J.M. 1965. Total nitrogen, p 1149-1178. In: C.A. Black (ed) Methods of Soil Analysis. Agronomy Monogr. \#9, Amer. Soc. Agron. Madison, Wis.

Fairbourn, M.L. 1980. The grass tetany potential of some Wyoming forages. Univ. Wyoming, Res. J. 154.

Fairbourn, M.L., and A.R. Batchelder. 190. Factors influencing magnesium in High Plains forage. J. Range Manage. 33:435-438.

Gardner, H.R., and W.R. Gardner. 1969. Relation of water application to evaporation and storage of soil water. Soil Sci. Soc. Amer. Proc. 33:192-196.

Houston, W.R., and D.N. Hyder. 1975. Ecological effect and fate of N following massive $\mathbf{N}$ fertilization of mixed grass plains. J. Range Manage. 28:56-60.

Jackson, M.L. 1958. Soil chemical analysis. Prentice Hall Inc., Englewood Cliffs, N.J. p. 151-153.

Johnston, A., S. Smoliak, A.D. Smith, and L.E. Lutwick. 1967. Improvement of southeastern Alberta range with fertilizer. Can. J. Plant Sci. 47:671-678.

Lodge, R.W. 1959. Fertilization of native range in the northeastern Great Plains. J. Range Manage. 12:277-279.

Lorenz, R.J., and G.A. Rogler. 1972. Forage production and botanical composition of mixed prairie as influenced by nitrogen and phosphorus fertilization. Agron. J. 64:244-249,

National Research Council. 1968. Nutritional requirements of domestic animals No. 5. Revised, nutrient requirements of sheep. Nat. Res. Counc., Washington, D.C.

National Research Council. 1970. Nutritional requirements of domestic animals No. 4. Revised, nutritional requirements of beef cattle. Nat. Res. Counc., Washington, D.C.

Power, J.F. 1981. Long-term recovery of fertilizer nitrogen applied to a native mixed prairie. Soil Sci. Soc. Amer. J. 45:782-786.

Rauri, F. 1977. High rates of nitrogen change composition of shortgrass rangeland in southeastern Wyoming. J. Range Manage. 31:366-370.

Rogler, G.A., and R.J. Lorenz. 1957. Nitrogen fertilization of Northern Great Plains rangeland. J. Range Manage. 10:156-160.

Samuel, M.J., F. Rauzi, and R.H. Hart. 1980. Nitrogen fertilization of range: yield, protein content, and cattle behavior. $J$. Range Manage. 3:119-121.

Smika, D.E., H.J. Haas, and J.F. Power. 1965. Effects of moisture and nitrogen fertilizer on growth and water use by native grass. Agron. J. $57: 483-486$.

Westin, F.C., G.J. Buntley, and B.C. Brage. 1955. Soil and weather. S. Dakota Agr. Exp. Sta. Circ. 116. Agr. Res. 6-18.

Wight, J.R., and A.L. Black. 1979. Range fertilization: plant response and water use. J. Range Manage. 32:345-349.

Woodmansee, R.G., J.L. Dodd, R.A. Bowman, F.E. Clark, and C.E. Kinson. 1978. Nitrogen budget of a shortgrass prairie ecosystem. Oecologia (Berl) 34:363-376.

Young, J.F., and P.C. Singleton. 1977. Wyoming general soil map. Univ. of Wyoming, Research J. 117. 